\title{
Helicobacter pylori infection and immune profile of patients with different gastroduodenal diseases
}

\author{
Ruth Maria Dias Ferreira VINAGRE ${ }^{1}$, Igor Dias Ferreira VINAGRE ${ }^{2}$, Adenielson VILAR-e-SILVA ${ }^{3}$, \\ Amanda Alves FECURY ${ }^{3}$ and Luisa Caricio MARTINS ${ }^{3}$
}

Received 10/9/2017 Accepted 9/1/2018

\begin{abstract}
Background - The association between infection with Helicobacter pylori and different gastroduodenal diseases is related to bacterial, host and environmental factors. Studies have demonstrated an association between the genetic diversity of $H$. pylori, especially in the $v a c A$ and $c a g A$ genes, and the development of digestive diseases such as peptic ulcer and gastric cancer. In addition, the nature of the host inflammatory response may explain these different manifestations of infection caused by this microorganism. In this respect, host factors that regulate the immune and inflammatory responses involving the functional interaction of $\mathrm{H}$. pylori infection with different components of the immune system, particularly $\mathrm{T}$ cells, in gastroduodenal diseases still need further investigation. Objective - To characterize the immune response, including immunity induced by infection with $H$. pylori, especially virulent strains ( $v a c A$ alleles and $\operatorname{cag} A$ gene), by analyzing the cytokine profile and T-cell population present in gastroduodenal diseases in a Brazilian population. Methods - In a prospective study, gastric biopsies were collected from 554 patients with different gastroduodenal diseases for histological analysis and for the determination of bacterial genotype and cytokine production (IL-4, IL-10, IFN- $\gamma$ and IL-12) by ELISA. Results - The predominant genotype of the $H$. pylori strains isolated from the patients studied was $s 1 m 1 \mathrm{cag} A+$, which was more common among patients with gastric ulcer, duodenal ulcer and gastric cancer. A significant association was observed between the $s 1 m 1 \mathrm{cag} A+$ genotype and a higher degree of inflammation, higher neutrophil activity and the development of intestinal metaplasia. The gastric concentrations of IFN- $\gamma$ and IL-12 were significantly higher in patients infected with $H$. pylori than in uninfected individuals. Higher levels of these cytokines were detected in patients with gastric ulcer and cancer, while the levels of IL- 4 and IL-10 in the gastric mucosa were lower in these patients. In addition, IFN- $\gamma$ and IL-12 concentrations in gastric biopsies were higher in patients infected with the virulent $\operatorname{siml~cag} A+$ genotype. In contrast, IL-4 and IL-10 levels were higher in tissue infected with $s 2 m 2 \mathrm{cag} A$ in gastric biopsies. Conclusion - Our study shows that the interaction between the type of infectious strain and the Th1 immune response can influence and perpetuate gastric inflammation, and thus contributes to the development of the different clinical manifestations of $H$. pylori infection.
\end{abstract}

HEADINGS - Gastrointestinal diseases. Mucosal immunity. Helicobacter pylori. Bacterial genes. Cytokines, immunology. Virulence factors, genetics.

\section{INTRODUCTION}

Helicobacter pylori is a gram-negative spiral bacterium that colonizes the gastroduodenal mucosa of humans. This microorganism is involved in the development of a number of gastroduodenal diseases such as chronic gastritis, peptic ulcer, carcinoma, and gastric lymphoma ${ }^{(1-3)}$. Although half of the world's population is infected with this bacterium, $80 \%$ of these individuals remain without clinical evidence of the disease ${ }^{(3)}$ and only a small percentage (probably less than $3 \%$ ) develop neoplasms related to the presence of $H$. pylori ${ }^{(4)}$. This wide variability in the clinical manifestations of $H$. pylori infection has been associated with different factors, such as bacterial virulence factors, environmental factors and host genetic factors ${ }^{(5-7)}$.

Several studies have demonstrated the genotype diversity of $H$. pylori strains. The products of these strains trigger an inflammatory process through mediators and cytokines that results in different degrees of the inflammatory response in the host and consequently different pathological conditions ${ }^{(8-10)}$. The main virulence factors of $H$. pylori are vacuolating cytotoxin A (VacA) and cytotoxin- associated gene $\mathrm{A}$ (CagA). Cytotoxin $\mathrm{CagA}$ is encoded by the $\operatorname{cag} \mathrm{A}$ gene, which is located on the cag pathogenicity island (cag-PAI), and is used as a marker of this island. Infection with CagA-positive $H$. pylori strains has been associated with the induction of an intense inflammatory response characterized by a dense infiltrate of neutrophils in the gastric mucosa ${ }^{(9)}$. The action of VacA causes the formation of vacuoles in gastric epithelial cells and consequent cell destruction. Thus, the identification of vacA alleles and of the $\operatorname{cag} A$ gene has been shown to be clinically relevant ${ }^{(5,9)}$.

Strains harboring a functional CagA-PAI and the vacA s $1 / \mathrm{ml}$ genotype have been detected at a higher frequency in patients with duodenal ulcer, atrophic gastritis and gastric cancer compared to strains lacking these virulence factors ${ }^{(10,11)}$. Recent studies have also reported this association in Brazil ${ }^{(12,13)}$. However, bacterial virulence factors alone are not sufficient to determine the clinical evolution of infection. Other host factors, particularly those regulating the immune and inflammatory response, also contribute to the development of gastroduodenal diseases and influence progression to more severe presentations ${ }^{(10,14)}$.

Declared conflict of interest of all authors: none

Disclosure of funding: no funding received

Research performed at: Núcleo de Medicina Tropical, Universidade Federal do Pará, Belém, PA, Brasil.

${ }^{1}$ Universidade Estadual do Pará, Departamento de Saúde Integrada, Belém, PA, Brasil. ${ }^{2}$ Universidade Federal do Pará, Belém, PA, Brasil. ${ }^{3}$ Universidade Federal do Pará, Laboratório de Patologia Clínica de Doenças Tropicais, Belém, PA, Brasil.

Corresponding author: Ruth Maria Dias Ferreira Vinagre. E-mail: ruthdfv@hotmail.com 
Local inflammation in $H$. pylori infection is characterized by the infiltration of neutrophils and specific lymphocytes into the gastric mucosa and by the increased production of various cytokines. Immunoregulatory and proinflammatory cytokines induced by $H$. pylori can influence the nature of the local T-cell response $^{(10,15)}$. Stimulation of helper T lymphocytes (CD4+) is observed during the specific immune response, which direct the immune response towards both the Th1 and Th2 profile. However, the cell-mediated response (Th1) predominates and most CD4+ cell clones, which are specific against $H$. pylori, secrete interferon gamma (IFN- $\gamma$ ) in response to antigen stimulation, indicating the Th1 phenotype of the immune response ${ }^{(3)}$. A humoral response is also observed, in which most of the antibodies produced against different bacterial antigens are of the IgG type; however, these antibodies do not confer protection nor prevent new infection ${ }^{(3)}$. The overall immune response that is unable to eliminate the microorganism results in a predominance of Th1 cells, while Th2 cells are practically absent during infection with $H$. pylori. This aberrant response of the host (Th1) to an organism that should induce secretory immune responses (Th2) may influence and perpetuate gastric inflammation ${ }^{(16)}$.

The objective of the present study was to evaluate the immune response induced by infection with $H$. pylori, particularly slmlcag $A+$ strains, in patients with different gastroduodenal diseases from the northern region of Brazil, and to associate these risk factors with the histopathological features of the gastric tissue.

\section{METHODS}

\section{Patients}

Gastric biopsy samples were collected from 554 patients with different gastroduodenal diseases seen at the Endoscopy Department of the Ofir Loiola Hospital between 2011 and 2013.

The gastric biopsies were obtained during upper digestive endoscopy. For DNA extraction, two biopsies were removed on average from the antral region, transferred to a sterile tube, and frozen for further analysis. Gastric biopsies were also obtained from the lesional and perilesional region for histopathological analysis and messenger of the cytokines (IL-4, IL-10, IFN- $\gamma$, and IL-12).

None of the patients had received antimicrobial drugs, H2receptor antagonists, acid pump inhibitors, nonsteroidal antiinflammatory drugs, or any medication for at least 60 days prior to endoscopy. All patients included in the study were of the same socioeconomic level, had similar cultural habits, were born in the state of Pará, and had the same ethnic background (approximately $50 \%$ Portuguese, $40 \%$ Amerindian, and $10 \%$ African $)^{(17)}$. The study was approved by the Ethics Committee of the Nucleus of Tropical Medicine, Federal University of Pará.

\section{Histopathological analysis}

The gastric fragments were stained with hematoxylin-eosin for histopathological analysis. For analysis of infiltration of polymorphonuclear and mononuclear cells, the histopathological parameters were graded from 0-3 according to the Sidney classification ${ }^{(18)}$.

\section{Extraction of DNA and PCR}

Total DNA was extracted from the frozen gastric biopsy specimens using the following procedure: $10 \mu \mathrm{L}$ proteinase $\mathrm{K}$ and 300 $\mu \mathrm{L}$ lysis buffer (200 mM Tris-HCl, 25 mM EDTA, $300 \mathrm{mM} \mathrm{NaCl}$,
$1.2 \%$ sodium dodecyl sulfate) were added to the biopsy specimens and the mixture was incubated for $12 \mathrm{~h}$ at $55^{\circ} \mathrm{C}$. The lysate was extracted with an equal volume of phenol-chloroform, precipitated with isopropanol, and washed with $70 \%$ ethanol. The pellet was dried and suspended in $200 \mu \mathrm{L}$ sterile distilled water. The extracted DNA was stored at $-20^{\circ} \mathrm{C}$.

For the detection of bacterial DNA, primers P1 and P2 that amplify a 298-bp fragment found in all $H$. pylori strains were used $^{(19)}$. Only patients in whom amplification with these primers (P1 and P2) occurred were typed for the vac $A$ alleles and $\operatorname{cag} A$ gene.

The protocol and primers described by Tumuru et al. (1993) $)^{(20)}$ were used for amplification of the $\operatorname{cag} A$ gene. The PCR products were separated by electrophoresis on $2 \%$ agarose gel stained with ethidium bromide and visualized under a UV transilluminator.

\section{Detection of IFN- $\gamma$, IL-4, IL-10 and IL-12}

Messenger of the cytokines (IL-4, IL-10, IFN- $\gamma$, and IL-12) was quantified by ELISA. Two biopsy specimens were frozen immediately in liquid nitrogen and stored at $-80^{\circ} \mathrm{C}$. These samples were later homogenized with $1 \mathrm{~mL}$ phosphate buffered saline $(\mathrm{pH}$ 7.4) for 1 minute at $4^{\circ} \mathrm{C}$. The homogenate was then centrifuged for 10 minutes at $14,000 \mathrm{rpm}$. The supernatant obtained was used for estimation of cytokines IL-10, IL-2, INF and TNF ${ }^{(21)}$. The citokines concentration was measured by ELISA kit (Thermo Fisher Scientific, Waltham, MA, USA) in a sandwich type assay using the procedure recommended by the manufacturer. The amount of citokines in the gastric mucosal biopsies was expressed as $\mathrm{pg} / \mathrm{mg}$ protein.

\section{Statistical analysis}

Odds ratios and G-tests were used to evaluate the proportion of risk factors in the control and patient groups. The level of significance was set at $95 \%$. Statistical analysis was performed using the BioEstat 5.0 program $^{(22)}$.

\section{RESULTS}

\section{Epidemiological data}

There was a predominance of males among patients with gastric ulcer $\left(\mathrm{x}^{2}=8.81 ; P=0.00\right)$ and gastric cancer $\left(\mathrm{x}^{2}=7.38 ; P=0.00\right)$ when compared to patients with gastritis and duodenal ulcer. The age of the patients ranged from 18 to 91 years. Patients with gastric ulcer and cancer were older than those of the other two groups studied $\left(\mathrm{x}^{2}=4.5 ; P=0.00\right)$.

DNA of $H$. pylori was detected by a molecular biology method (PCR) in gastric biopsies of $91 \%$ of the cases analyzed. Patients with duodenal ulcer who tested positive for $H$. pylori exhibited a higher frequency of the $\operatorname{cag} A$ gene than patients with gastritis, gastric ulcer and gastric cancer.

\section{Genotyping of the vacA alleles and $\operatorname{cag} A$ gene of $\boldsymbol{H}$. pylori}

Samples in which $H$. pylori DNA was detected were characterized for $v a c A$ and $\operatorname{cag} A$ genotypes. Analysis of these alleles showed that $97.6 \%(494 / 506)$ of the samples were monoinfected, i.e., they carried only one bacterial strain, and mixed infection was found in $12 / 506(2.4 \%)$. Genotyping of $v a c A$ revealed the signal region allele $s 1$ in $88 \%(446 / 506)$ of the samples. In the mid-region, allele $m 1$ predominated $(87 \%, 440 / 506)$. The $\operatorname{cag} A$ gene was detected in $85.6^{\%} \%(433 / 506)$ of the patients infected with $H$. pylori. 
Comparison of the different $v a c A$ and $\operatorname{cag} A$ genotypes showed a higher prevalence of the virulent $\operatorname{siml} \operatorname{cag} A+$ genotype in monoinfected patients. A predominance of genotype $\mathrm{s} / \mathrm{ml} /$ s2m2cag $A+$ was observed in patients infected with multiple strains. Another genotype found in mixed infections was $\mathrm{s} 1 \mathrm{ml} /$ s2m2cagA- (TABLE 1).

TABLE 1. Prevalence of cytotoxin-associated gene A ( cagA) and different allele combinations of the vacA gene in patients with different gastroduodenal diseases.

\begin{tabular}{|c|c|c|c|c|c|}
\hline Genotype & $\mathbf{N}$ & Gastritis & $\begin{array}{l}\text { Gastric } \\
\text { ulcer }\end{array}$ & Cancer & $\begin{array}{l}\text { Duodenal } \\
\text { ulcer }\end{array}$ \\
\hline
\end{tabular}

Monoinfection

$\begin{array}{lccccc}s 1 m 1 \operatorname{cag} A+ & 422 & 188(77) & 44(86.3) & 126(86.9) & 64(97) \\ s 1 m 1 c a g A- & 6 & 4(1.6) & - & 2(1.4) & - \\ s 1 m 2 \operatorname{cag} A- & 6 & 6(2.5) & - & - & - \\ s 2 m 2 \operatorname{cag} A- & 60 & 38(15.6) & 6(11.8) & 14(9.6) & 2(3)\end{array}$

Mixed infection

\begin{tabular}{lccccc}
$s 1 m 1 /$ & 11 & $8(3.3)$ & $1(1.9)$ & $2(1.4)$ & - \\
$s 2 m 2 c a g A+$ & & & & & \\
$\begin{array}{l}s 1 m 1 / \\
s 1 m 2 c a g A-\end{array}$ & 1 & - & - & $1(0.7)$ & - \\
Total & 506 & $244(100)$ & $51(100)$ & $145(100)$ & $66(100)$ \\
\hline
\end{tabular}

\section{Frequency of the association of different genotypes in patients with gastroduodenal diseases}

Correlation between the endoscopic diagnosis of gastroduodenal disorder and $H$. pylori strain showed that the virulent $\operatorname{simlcag} A+$ genotype was more frequent in patients with gastric ulcer $(\mathrm{G}=34.18 ; P=0.001)$, duodenal ulcer $(\mathrm{G}=62.04 ; P=0.001)$ and gastric cancer $(\mathrm{G}=62.52 ; P=0.001)$ than in those with gastritis (TABLE 1).

\section{Association between $H$. pylori genotypes and histopathological findings}

Only monoinfected patients were studied for the comparison of different bacterial strains and histopathological findings $(n=494)$. Regarding the degree of inflammation and neutrophil activity in gastric tissue, patients carrying genotype $\operatorname{siml} \operatorname{cag} A+$ exhibited a higher degree of inflammation and higher neutrophil activity than those infected with the other strains (TABLE 2).
Intestinal metaplasia was observed in $24.5 \%$ (121/494) of monoinfected patients, most of them carrying genotype $\operatorname{simlcag} A+$ in the gastric mucosa (TABLE 3).

TABLE 3. Association of the different vacA alleles and presence of the $\operatorname{cag} A$ gene with intestinal metaplasia.

\begin{tabular}{|c|c|c|c|c|}
\hline $\operatorname{vac} \mathrm{A}$ & $\operatorname{cag} A$ & \multicolumn{2}{|c|}{ Metaplasia } & $\mathrm{OR} / P$-value \\
\hline allele & & Present & Absent & $(95 \% \mathrm{CI})$ \\
\hline$s 1 \mathrm{~m} 1$ & $(+)$ & 117 & 305 & \\
\hline$s 1 m 1$ & $(-)$ & 1 & 5 & $7.28 / 0.0003$ \\
\hline$s 1 m 1$ & $(-)$ & - & 6 & $2.23-23.72$ \\
\hline$s 2 m 2$ & $(-)$ & 3 & 57 & \\
\hline
\end{tabular}

OR: odds ratio; $95 \%$ CI: 95\% confidence interval.

\section{Measurement of cytokines in different gastroduodenal diseases}

Differences were observed in the concentrations of cytokines (IFN- $\gamma$, IL-12, IL- 4, and IL-10) in the gastric mucosa of patients with different gastroduodenal diseases. The levels of IFN- $\gamma$ and IL12 were higher in the groups with gastric ulcer $(P<0.05)$ and gastric cancer $(P<0.05)$. In addition, lower levels of IL-4 and IL-10 were detected in these groups when compared to patients with gastritis $(P<0.05)$ and duodenal ulcer $(P<0.05)$ (FIGURE 1$)$.

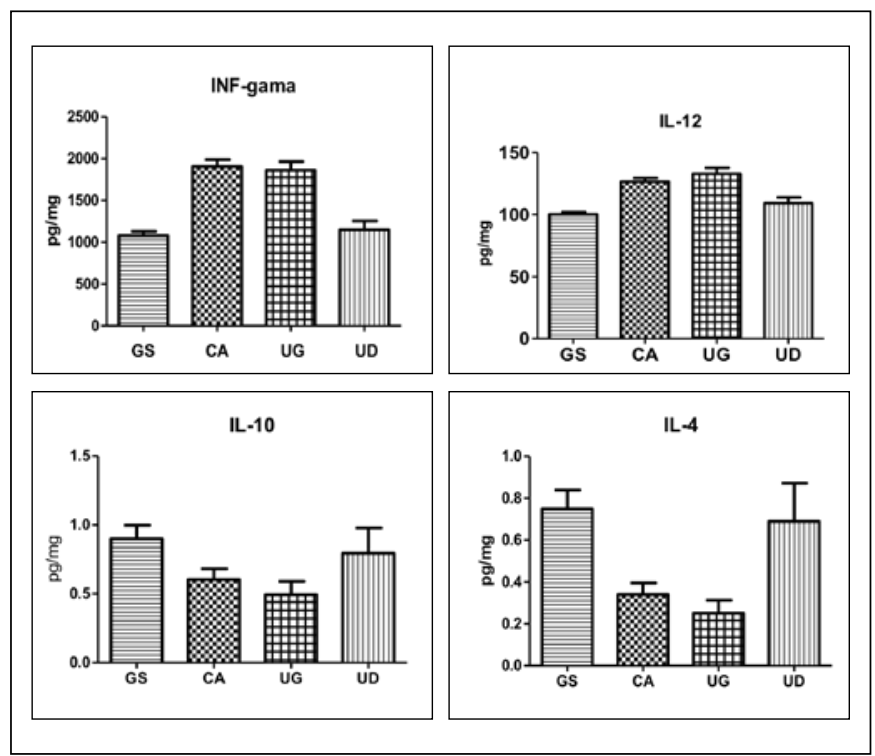

FIGURE 1. Concentration $(\mathrm{pg} / \mathrm{mg})$ of cytokines in gastric biopsies of patients with different gastroduodenal diseases. Results are reported as the mean \pm standard deviation. GS: gastritis; GC: gastric cancer; GU: gastric ulcer; DU: duodenal ulcer.

TABLE 2. Association of the different vacA alleles and presence of the cagA gene with histopathological data (degree of inflammation and neutrophil activity) of monoinfected patients.

\begin{tabular}{|c|c|c|c|c|c|c|c|}
\hline vacA & $\operatorname{cag} A$ & & & OR/P-value & & & OR/P-value \\
\hline allele & & 1 & 2 and 3 & $(95 \% \mathrm{CI})$ & 1 & 2 and 3 & $(95 \% \mathrm{CI})$ \\
\hline$s 1 m 1$ & $(+)$ & 96 & 326 & - & 86 & 336 & - \\
\hline$s 1 m 1$ & $(-)$ & 6 & - & $4.72-14.39$ & 6 & - & $6.53-21.01$ \\
\hline$s 2 m 2$ & $(-)$ & 44 & 16 & & 45 & 15 & \\
\hline
\end{tabular}

DI: degree of inflammation; NA: neutrophil activity; OR: odds ratio; $95 \%$ CI: $95 \%$ confidence interval. 


\section{Measurement of cytokines in infection with different H. pylori strains}

The gastric concentrations of IFN- $\gamma$ and IL-12 were significantly higher in patients infected with $H$. pylori compared to uninfected patients, while IL-4 and IL-10 concentrations were lower.

The concentrations of IFN- $\gamma$ and IL-12 in gastric biopsies were also higher in patients carrying the virulent $\operatorname{siml} \operatorname{cag} A+$ genotype compared to patients infected with other strains. In contrast, IL-4 and IL-10 levels were higher in tissue infected with $s 2 \mathrm{~m} 2 \mathrm{cag} A$ strains (TABLE 4).

TABLE 4. Comparison of cytokine concentration ( $\mathrm{pg} / \mathrm{mg}$ ) according to the presence or absence of infection with Helicobacter pylori and between the different bacterial strains found.

\begin{tabular}{lcccc}
\hline $\begin{array}{l}\text { Molecular } \\
\text { biology }\end{array}$ & IFN- $\boldsymbol{I L}$ & IL-12 & IL-4 & IL-10 \\
\hline $\begin{array}{l}\text { H. pylori } \\
\text { Negative }\end{array}$ & $673 \pm 1.61$ & $74 \pm 1.50$ & $0.47 \pm 2.89$ & $0.64 \pm 2.52$ \\
$\quad \begin{array}{c}\text { Positive } \\
\text { Strains }\end{array}$ & $1335 \pm 1.52$ & $108 \pm 1.40$ & $0.28 \pm 2.28$ & $0.42 \pm 1.85$ \\
s1m1cagA+ & $1.414 \pm 1.43$ & $115 \pm 1.39$ & $0.27 \pm 2.77$ & $0.46 \pm 1.87$ \\
$s 1 m 1$ cagA- & $910 \pm 1.36$ & $108 \pm 1.12$ & $0.29 \pm 1.91$ & $0.48 \pm 1.68$ \\
$s 1 m 2$ cagA- & $778 \pm 1.12$ & $105 \pm 1.14$ & $0.31 \pm 2.06$ & $0.44 \pm 2.28$ \\
s2m2cagA- & $1.046 \pm 1.56$ & $103 \pm 1.54$ & $0.38 \pm 3.01$ & $0.60 \pm 1.89$ \\
\hline
\end{tabular}

Values are the mean \pm standard deviation. Kruskal-Wallis test.

\section{Association between cytokine concentration and histopathological findings}

The comparison of cytokine concentration in the gastric mucosa and histopathological findings showed higher levels of IFN- $\gamma$ and IL-12 in patients exhibiting a higher degree of inflammation, higher neutrophil activity and intestinal metaplasia. In these patients, lower concentrations of IL-4 and IL-10 in gastric biopsies were demonstrated when compared to patients with mild inflammation and neutrophil activity and no intestinal metaplasia (TABLE 5).

TABLE 5. Comparison of cytokine concentration $(\mathrm{pg} / \mathrm{mg})$ in gastric biopsies with the histopathological findings.

\begin{tabular}{lcccc}
\hline Histopathology & IFN- $\boldsymbol{\gamma}$ & IL-12 & IL-4 & IL-10 \\
\hline DI & & & & \\
Mild & $1100 \pm 1.62$ & $96 \pm 1.47$ & $0.65 \pm 2.17$ & $0.42 \pm 3.25$ \\
Moderate/intense & $1340 \pm 1.56$ & $109 \pm 1.41$ & $0.52 \pm 1.95$ & $0.28 \pm 2.73$ \\
$P$-value & $<0.05$ & $<0.05$ & $<0.05$ & $<0.05$ \\
NA & & & & \\
Mild & $1126 \pm 1.64$ & $96 \pm 1.47$ & $0.63 \pm 1.47$ & $0.41 \pm 3.22$ \\
Moderate/intense & $1324 \pm 1.23$ & $108 \pm 1.40$ & $0.53 \pm 2.15$ & $0.27 \pm 2.61$ \\
$P$-value & $<0.05$ & $<0.05$ & $<0.05$ & $<0.05$ \\
Metaplasia & & & & \\
Present & $1428 \pm 1.52$ & $113 \pm 1.37$ & $0.24 \pm 2.70$ & $0.34 \pm 1.92$ \\
Absent & $1212 \pm 1.60$ & $103 \pm 1.45$ & $0.34 \pm 2.70$ & $0.44 \pm 2.01$ \\
$P$-value & $<0.05$ & $<0.05$ & $<0.05$ & $<0.05$ \\
\hline
\end{tabular}

Values are the mean \pm standard deviation. Kruskal-Wallis test. DI: degree of inflammation; NA: neutrophil activity. IFN: interferon gamma. IL: interleukin.

\section{DISCUSSION}

The objective of this study was to establish the association of the immune response induced by $H$. pylori infection with different gastroduodenal diseases and the histopathological alterations found in these cases. Bacterial virulence factors play an important role in the development of these gastroduodenal diseases since virulent strains are more aggressive and increase the risk of more severe clinical manifestations. Furthermore, host factors, particularly those that regulate the immune and inflammatory responses, can influence the progression to more severe forms of infection ${ }^{(23,24)}$.

Comparison of the frequency of sex and age between the different gastroduodenal diseases showed a predominance of males among patients with gastric ulcer and gastric cancer and these patients were older than those of the other two groups studied. Studies have reported a higher incidence of gastric ulcer and cancer in patients above the age of 50 because of the occurrence of sequential metaplastic changes in the gastric mucosa secondary to $H$. pylori infection that can progress to dysplasia and neoplasms ${ }^{(25,26)}$. The higher frequency of gastric ulcer and gastric cancer in men has been explained by the participation of environmental and lifestyle factors in places where men are more commonly exposed to stress, alcohol consumption and smoking ${ }^{(25-27)}$.

The prevalence of $H$. pylori infection diagnosed by a molecular biology method (PCR) was 91\% among patients with different gastroduodenal diseases. Similar results have been reported in other studies using this diagnostic method ${ }^{(12,13,28,29)}$. Most patients $(97.6 \%)$ were infected with only one type of bacterial strain (monoinfection) and $2.4 \%$ were infected with more than one strain (mixed infection). In Brazil, the frequency of multiple infections ranges from $3.4 \%$ to $17 \%$ depending on the population studied and the region where the study was carried out ${ }^{(12,28,29,30)}$.

Characterization of $v a c A$ alleles and of the presence of the $\operatorname{cag} A$ gene showed a predominance of genotype $\operatorname{simlcag} A+$ in this study. Patients with gastric ulcer, duodenal ulcer and gastric cancer exhibited a higher frequency of the virulent $\operatorname{simlcag~} \mathrm{A}^{+}$ genotype than patients with gastritis. With respect to the association between vac $A$ and $\operatorname{cag} A$ genotypes and the histopathological findings, patients infected with $\operatorname{simlcag} A+$ strains had a higher degree of inflammation and neutrophil activity in the gastric mucosa, as well as an increased risk of developing intestinal metaplasia. These data support the correlation of pathogenic $v a c A$ and $\operatorname{cag} A$ genotypes of $H$. pylori with chronic aggression to the gastric mucosa and greater DNA damage to epithelial cells, events that contribute to the development of peptic ulcers and gastric cancer ${ }^{(5,29,31,32)}$.

In addition to the presence of different virulent strains in patients infected with $H$. pylori, the nature of the host immune response has been studied as one of the determinant factors for the development of different clinical manifestations in these patients $^{(3,16)}$. Infection with $H$. pylori induces a predominant CD4+ Tcell response and many studies have shown that most clones of these cells produce IFN- $\gamma$, indicating a Th1 phenotypic response ${ }^{(33-35)}$. The cytokines produced by this phenotype are unable to eradicate the bacterium and contribute to the development of more severe clinical manifestations ${ }^{(23,24)}$.

In the present study, the gastric concentrations of IFN- $\gamma$ and IL-12 were significantly higher and the concentrations of IL-4 and IL-10 were lower in patients infected with $H$. pylori than in uninfected patients. Comparison of cytokine concentration (IFN- $\gamma$, 
IL-12, IL-4, and IL-10) in the gastric mucosa revealed differences between patients with different gastrointestinal diseases. The levels of IFN- $\gamma$ and IL-12 were higher in the groups with gastric ulcer and gastric cancer and lower levels of IL-4 and IL-10 were detected in these groups when compared to patients with gastritis and duodenal ulcer. This relationship of increased IFN- $\gamma$ and IL-12 levels with the development of peptic ulcer and more severe clinical manifestations has been demonstrated in other studies ${ }^{(10,36)}$.

Analysis of cytokine concentration in gastric biopsies of patients infected with different bacterial strains showed higher concentrations of IFN- $\gamma$ and IL-12 in patients infected with the virulent $\operatorname{simlcag} A+$ genotype compared to those carrying other strains. In contrast, IL-4 and IL-10 levels were higher in tissue infected with $s 2 m 2 \operatorname{cag} A$ - strains.

Comparison between cytokine concentration in the gastric mucosa and the histopathological findings showed higher levels of IFN- $\gamma$ and IL-12 in patients with a higher degree of inflammation and neutrophil activity and a greater relationship with the presence of intestinal metaplasia. In addition, lower concentrations of IL-4 and IL-10 in gastric biopsies were observed in these patients when compared to those with mild inflammation and neutrophil activity and no intestinal metaplasia.
Taken together, these findings suggest that Th1 cells contribute to the magnitude of the inflammatory response in $H$. pylori infection. Thus, the inappropriate regulation of the host response to the luminal microbiota is paramount in determining whether the host will develop protective immunity or chronic inflammation ${ }^{(37)}$.

The present results indicate that the interaction between the type of $H$. pylori strain and the immune response profile of the host contributes to chronicity of the disease and progression to more severe gastric disorders and may explain the different clinical manifestations of infection caused by this microorganism. These findings agree with data suggesting a higher frequency of a Th1 immune response in gastric biopsies of patients with peptic ulcer and gastric cancer infected with $H$. pylori genotype $\operatorname{simlcag} A+$. The results are useful to identify patients who are at an increased risk of developing more severe lesions and, thus, may assist in the prognostic evaluation and treatment of these cases.

\section{Authors' contribution}

Vinagre RMDF: research execution, statistical analysis, data collect, text writing. Vinagre IDF: data collect, text writing. Vilar e Silva A: determination of bacterial genotype. Fecury AA: determination of cytokine production. Martins LC: histological analysis.

Vinagre RMDF, Vinagre IDF, Vilar e Silva A, Fecury AA, Martins LC. Infecção pelo Helicobacter pylori e perfil imunológico em pacientes com diferentes doenças gastroduodenais. Arq Gastroenterol. 2018;55(2):122-7.

RESUMO - Contexto - A associação da infecção por Helicobacter pylori com diferentes doenças gastroduodenais pode estar associada a fatores bacterianos, do hospedeiro e do ambiente. Nesse contexto, estudos têm demonstrado que a diversidade genética do $H$. pylori, sobretudo nos genes vacA e $\operatorname{cag} A$, está associada ao desenvolvimento de doenças gastroduodenais como a úlcera péptica e o câncer gástrico. Além disso, a natureza da resposta inflamatória do hospedeiro pode explicar essas diferentes manifestações da infecção por esse microrganismo. Portanto, fatores do hospedeiro que regulam as respostas imunológica e inflamatória, envolvendo a interação funcional da infecção por $H$. pylori com diferentes membros do compartimento imunológico, especialmente respostas imunes de células T nas doenças gastroduodenais, ainda precisam ser melhor estudados. Objetivo - Caracterizar a resposta imune, incluindo imunidade induzida por infecção pelo H. pylori, especialmente com cepas virulentas de H. pylori (alelos vacA e gene cagA), através da análise do perfil de citocinas e da caracterização da população de células T presentes em doenças gastroduodenais em nossa população. Métodos - Em um estudo prospectivo, foram coletadas biópsias gástricas de 554 pacientes portadores das diferentes doenças gastroduodenais. Nas amostras biológicas destes pacientes foi realizada a determinação do genótipo bacteriano e a detecção das citocinas IL-4, IL-10, INF- $\gamma$ e IL-12 através do método Elisa. Foram obtidas biópsias gástricas para avaliação histológica. Resultados - Observamos que o genótipo predominante nas cepas de H. pylori isoladas dos pacientes estudados foi $\operatorname{siml} \operatorname{cag} A$ positivo, sendo mais frequentes entre os pacientes com úlcera gástrica, úlcera duodenal e câncer gástrico. Houve associação significativa das cepas com o genótipo $\operatorname{siml}$ cag $A$ positivo com maior grau de inflamação, atividade neutrofílica e desenvolvimento de metaplasia intestinal. As concentrações gástricas de INF- $\gamma$ e IL-12 foram significativamente mais elevadas em pacientes infectados pelo H. pylori do que nos não infectados. Foram detectados níveis mais elevados dessas citocinas nos portadores de úlcera e câncer gástrico, sendo que nesses pacientes foram observados níveis mais baixos de IL-4 e IL-10 na mucosa gástrica. Além disso, as concentrações de INF- $\gamma$ e IL-12 em biópsias gástricas, foram mais elevadas nos pacientes portadores das cepas bacterianas virulentas slm1 cag $A+$. Contrariamente, os níveis de IL-4 e IL-10 foram maiores em tecido infectado por cepas $s 2 m 2 \operatorname{cag} A$. Pacientes com maior grau de inflamação, de atividade neutrofílica e presença de metaplasia intestinal, apresentaram níveis mais elevados de INF- $\gamma$ e IL-12 e uma concentração mais baixa de IL-4 e IL-10 nas biópsias gástricas. Conclusão - Nosso estudo demonstra que a interação entre o tipo de cepa infectante e resposta imunológica com perfil Th1, podem influenciar e perpetuar a inflamação gástrica contribuindo para o desenvolvimento de diferentes manifestações clínicas na infecção pelo H. pylori.

DESCRITORES - Gastroenteropatias. Imunidade nas mucosas. Helicobacter pylori. Genes bacterianos. Citocinas, imunologia. Fatores de virulência, genética. 


\section{REFERENCES}

1. Covacci A, Telford LJ, Giudice DG, Parsonnet J, Rappuoli R. Helicobacter pylori virulence and genetic geography. Science. 1999;284:1328-33.

2. César ACG, Silva AE, Tajara EH. Fatores genéticos e ambientais envolvidos na carcinogênese gástrica. Arq Gastroenterol. 2002;39:253-59.

3. Suerbaum S, Michetti P. Helicobacter pylori infection. N Engl J Med. 2002;347:1175-86.

4. Go MF. Review article: natural history and epidemiology of Helicobacter pylori infection. Aliment Pharmacol Ther. 2002;16:3-15.

5. Atherton JC. The clinical relevance of strain types of Helicobacter pylori. Gut. 1997;40:701-03.

6. Shiotane A, Nurgalieva ZZ, Yamaoka Y, Graham DY. Helicobacter pylori. Med Clin North Am. 2000;84:1125-36.

7. Vinagre, RMDF, Vilar-e-Silva, A, Fecury, AA, Martins, LC. Role of Helicobacter pylori infection and lifestyle habits in the development of gastroduodenal diseases in a population from the Brazilian Amazon. Arq Gastroenterol. 2013;50:170-4.

8. Nomura M, Lee J, Temmermann GN, Nomura RY, Perez-Perez GI, Blaser MJ. Helicobacter pylori CagA seropositivity and gastric carcinoma risk in a Japanese American population. J Infect Dis. 2002;186:1138-44.

9. Higashi H, Nakaya A, Tsutsumi R, Yokoyama K, Fujii Y, Ishikawa S, et al. Helicobacter pylori CagA induces Ras-independent morphogenetic response through SHP-2 recruitment and activation. J Biol Chem. 2004;23:17205-16.

10. Serrano C, Diaz MI, Valdivia A, Godoy A, Pena A, Rollan A, et al. Relationship between Helicobacter pylori virulence factors and regulatory cytokines as predictors of clinical outcome. Microbes Infect. 2007;9:428-3.

11. Monack DM, Mueller A, Falkow S. Persistent bacterial infections: the interface of the pathogen and the host immune system. Nature Rev Microbiol. 2004;2:747-65.

12. Vinagre RMDF, Corvelo TCO, Arnaud VC, Leite ACK, Barile KAS, Martins LC. Determination of strains of Helicobacter pylori and of polymorphism in the interleukin-8 gene in patients with stomach cancer. Arq Gastroenterol. 2011;48:46-51.

13. Silva Jr MR, Vinagre RMDF, Silva AV, Oliveira CSF, Santos KN, Costa RAA, et al. Differences in virulence markers between Helicobacter pylori strains from the Brazilian Amazon region. Rev Soc Bras Med Trop. 2013;46:358-61.

14. Machado JC, Figueiredo C, Canedo P, Pharoah P, Carvalho R, Nabais S, et al. A proinflammatory genetic profile increases the risk for chronic atrophic gastritis and gastric carcinoma. Gastroenterology. 2003;125:364-71.

15. Sommer F, Faller G, Konturek P, Kirchner T, Hahn EG, Zeus J, et al. Antrum and corpus mucosa-infiltrating CD4+ lymphocytes in Helicobacter pylori gastritis display a Th1 phenotype. Infect Immun. 1998;6:5543-46.

16. Israel DA, Peek RM. Review article: pathogenesis of Helicobacter pylori-induced gastric inflammation. Aliment Pharmacol Ther. 2001;15:1271-90.

17. Santos SEB, Guerreiro JF. The indigenous contribution to the formation the population of the Brazilian Amazon region. Genet Mol Biol. 1995;18:311-15.

18. Dixon MF. Pathology of gastritis and peptic ulceration. In: HLT Mobley,.GL Mendz, SL Hazell. eds. Helicobacter pylori: physiology and genetics. Washington, D.C. ASM Press. 2001; p. 459-60.

19. Hammar M, Tysziewicz T, Wadstrom T, O'Toole PW. Rapid detection of Helicobacter pylori in gastric biopsy material by polymerase chain reaction. $\mathrm{J}$ Clin Microbiol. 1992;30:54-8.

20. Tummuru MK, Cover TL, Blaser MJ. Cloning and expression of a high molecular mass major antigen of Helicobacter pylori: evidence of linkage to cytotoxin production. Infect Immun. 1993;61:1799-809.

21. Yamaoka Y, Kita M, Kodama T, Sawai N, Kashima K, Imanishi J. Induction of various cytokines and development of severe mucosal inflammation by cagA gene positive Helicobacter pylori strains. Gut. 1997;41:442-51.
22. Ayres M, Ayres MJ, Ayres DL, Santos AS. BioEstat 5.0. Aplicações estatísticas nas áreas das ciências biológicas e médicas. Sociedade Civil Mamirauá MCT CNPq, Belém, 2007:364p.

23. Wang SK, Zhu HF, He BS, Zhang ZY, Chen ZT, Wang ZZ, Wu GL. CagA+ $H$. pylori infection is associated with polarization of $\mathrm{T}$ helper cell immune responses in gastric carcinogenesis. World J Gastroenterol. 2007;13:2923-31.

24. Romero-Adrián TB, Leal-Montiel J, Monsalve-Castillo F, Mengual-Moreno E, McGregor EG, Perini L, Antúnez A. Helicobacter pylori: bacterial factors and the role of cytokines in the immune response. Curr Microbiol. 2010; 60:143-55.

25. Komen NA, Bertleff MJ, Van Doorn LJ, Lange JF, de Graaf PW. Helicobacter genotyping and detection in perioperative lavage fluid in patients with perforated peptic ulcer. J Gastrointest Surg. 2008;12:555-60.

26. Casali JJ, Franzon O, Kruel NF, Neves BD. Análise epidemiológica e emprego do teste rápido da urease em pacientes com úlcera péptica perfurada. Rev Col Bras Cir. 2012;39:93-98.

27. Coelho LGV, Coelho MCF. Peptic disease and Helicobacter pylori. Rev Bras Med. 2007;64:123-7.

28. Martins LC, Corvelo TC, Demachki S, Araujo MT, Assumpcao MB, Vilar SC, Freitas FB, Barbosa HP, Fecury AA, do Amaral RK, Dos Santos SE. Clinical and pathological importance of vacA allele heterogeneity and cagA status in peptic ulcer disease in patients from North Brazil. Mem Inst Oswaldo Cruz. 2005;100:875-81.

29. Thomazini CM, Pinheiro NA, Pardini MI, Naresse LE, Rodrigues MAM. Helicobacter pylori and gastric cancer: distribution of $\operatorname{cag} A$ and $v a c A$ genotypes in patients with gastric carcinoma. J Bras Patol Med Lab. 2006;42:25-30.

30. Ashour AAR, Magalhães PP, Mendes EN, Collares GB, Gusmão VR, Queiroz DMM, Nogueira AMMF, Rocha GA, Oliveira CA. Distribution of vacA genotypes in Helicobacter pylori strains isolated from Brazilian adult patients with gastritis, duodenal ulcer or gastric carcinoma. FEMS Immunol Med Microbiol. 2002;33:173-8.

31. Salama NR, Tompkins L, Falkow S. Vacuolating cytotoxin of Helicobacter pylori plays a role during colonization in a mouse model of infection. Infect Immun. 2001;69:730-6.

32. Ladeira MSP, Rodrigues MA, Salvadori DM, Neto PP, Achilles P, Lerco MM, et al. Relationships between cagA, vacA, and iceA genotypes of Helicobacter pylori and DNA damage in the gastric mucosa. Environ Mol Mutagen. 2004;44:91-8.

33. O'Keeffe J, Moran AP. Conventional, regulatory, and unconventional T cells in the immunologic response to Helicobacter pylori. Helicobacter. 2008;13:1-19.

34. Lundgren A, Trollmo C, Edebo A, Svennerhol AM, Lundin BS. Helicobacter pylori-specific CD4+ T cells home to and accumulate in the human Helicobacter pylori-infected gastric mucosa. Infect Immun. 2005;73:5612-9.

35. Luncgren A, Suri-Payer E, Enarsson K, Snennerholm AM, Lundin BS. Helicobacter pylori-specific CD4+ CD25high regulatory T cells suppress memory T-cell responses to $H$. pylori in infected individuals. Infect Immun. 2003;71:1755-62.

36. Amedei A, Cappon A, Codolo G, Cabrelle A, Polenghi A, Benagio M, Tasca E, Azzurri A, D'elio MM, Prete GD, Ernard M. The neutrophil-activating protein of Helicobacter pylori promotes Th1 immune responses. J Clin Invest. 2006;116:1092-101.

37. Dixon MF, Genta RM, Yardley JH, Correa P. Histological classification of gastritis and Helicobacter pylori infection: an agreement at last? The International Workshop on the Histopathology of Gastritis. Helicobacter. 1997 (Suppl. 1): S17-24. 